\title{
IMPROVING THE ACCURACY AND RELIABILITY OF AUTOMATIC VESSEL MOUTION CONTROL SYSTEM
}

Zinchenko S. M. - PhD, Senior Lecturer of Ship Handling Department, Head of the Electronic Simulators Laboratory, Kherson State Maritime Academy, Ukraine.

Ben A. P. - PhD, Professor of Navigation and Electronic Navigation Systems Department, Vice-rector for scientific and pedagogical work, Kherson State Maritime Academy, Ukraine.

Nosov P. S. - PhD, Associate Professor of Navigation Systems Department, Kherson State Maritime Academy, Ukraine.

Popovych I. S. - Doctor of Psychological Sciences, Professor of General and Social Psychology Department, Kherson State University, Ukraine

Mamenko P. P. - Senior Lecturer of Ship Handling Department, deep sea captain, Kherson State Maritime Academy, Ukraine.

Mateichuk V. M. - Senior Lecturer of Ship Handling Department, Head of the Electronic Simulators Laboratory, Kherson State Maritime Academy, Ukraine.

\begin{abstract}
Context. There were considered the issues of improving the accuracy and reliability of automatic vessel motion control systems in conditions of large deviations in sensors measurements during maneuvering and failures of sensors and actuators. The object of research is the process of automatic vessel motion control in conditions of large deviations in sensors measurements during maneuvering and failures of sensors and actuators. The subject of research is a method and algorithms for improving the accuracy and reliability of automatic vessel motion control systems in conditions of large deviations in sensors measurements during maneuvering and failures of sensors and actuators.
\end{abstract}

Objective. The aim of the research is development a method and algorithms for improving the accuracy and reliability of automatic vessel motion control systems in conditions of large deviations in sensors measurements during maneuvering and failures of sensors and actuators.

Method. This goal is achieved by using in onboard controller of the automatic vessel motion control systems an observer to estimation the parameters of the state vector in the linear motion channel by measurements of linear speed and position sensors; estimation the parameters of the state vector in the angular motion channel by measurements of rotational speed and angular position sensors; continuous monitoring of the measured information by comparing it with the obtained estimations; correction estimations in the linear motion channel by measurements of linear speed and position sensors that have passed control; correction estimations in the angular motion channel by measurements of rotational speed and angular position sensors that have passed control; formation of a sensor failure in the linear motion channel (linear speed sensor or position sensor), if its measurements differ from the corresponding estimations for a greater than permissible value, to parry the failure in the linear motion channel by disconnecting the failed sensor from the observer and further estimation according to another sensor working in pairs; formation of a sensor failure in the angular motion channel (rotation speed sensor or angular position sensor), if its measurements differ from the corresponding estimations for a greater than permissible value, to parry the failure in the angular motion channel by disconnecting the failed sensor from the observer and further estimation according to another sensor working in pair; formation of an actuators failure in the linear motion channel (engine, automation or other device) if a simultaneous or sequential failure of both sensors were detected - linear speed sensor and position sensor, actuator failure alarm in the linear motion channel; formation of an actuators failure in the angular motion channel (rudders, drives, other devices) if a simultaneous or sequential failure of both sensors were detected - rotation speed sensor and angular position sensor, actuator failure alarm in the angular motion channel. This method and algorithms make it possible to improve the accuracy and reliability of automatic vessel motion control processes in conditions of large deviations in sensors measurements during maneuvering and failures of sensors and actuators.

Results. The proposed method and algorithms for improving the accuracy and reliability of automatic vessel motion control systems in conditions of large deviations in sensors measurements during maneuvering and failures of sensors and actuators were verified by mathematical modeling in the MATLAB environment of the control object movement in a closed circuit with a control system for various types of vessels, navigation areas, weather conditions and cases of large deviations in sensors measurements during maneuvering and failures of sensors and actuators.

Conclusions. The results of mathematical modeling confirmed the efficiency of the developed method and algorithms and allow to recommend them for practical use in the development of mathematical support for automatic vessel motion control systems in conditions of large deviations in sensors measurements during maneuvering and failures of sensors and actuators.

KEYWORDS: parry equipment failure, observer, increased accuracy and reliability of control, mathematical model, onboard controller, state vector estimation, sensor, actuator.

\author{
ABBREVIATIONS \\ MATLAB is Matrix Laboratory; \\ $\mathrm{HF}$ is human factor; \\ GPS is Global Positioning System.
}

$\mathrm{BCS}$ is a bound coordinate system; is located in the vessel rotation center, the axis OX lies in the diametral plane and is directed toward the bow, the axis OY is directed perpendicular to diametral plane towards the 
starboard, the axis $\mathrm{OZ}$ complements the system to the "right" one.

GCS is a geographical coordinate system; is located in the vessel rotation center, the axis OXg is directed along the meridian towards the North, the axis OYg is directed along the parallel towards the East, the axis $\mathrm{OZg}$ complements the system to the "right" one.

\section{NOMENCLATURE}

$\mathbf{X}$ is a state vector of own vessel;

$V_{X}$ is a component of $\mathbf{X}$ - linear speed along the $\mathrm{OX}$ - axis BCS;

$V_{y}$ is a component of $\mathbf{X}$ - linear speed along the $\mathrm{OY}$ - axis BCS;

$V_{Z}$ is a component of $\mathbf{X}$ - linear speed along the $\mathrm{OZ}$ - axis BCS;

$\omega_{X}$ is a component of $\mathbf{X}-$ angular rate around the $\mathrm{OX}$ - axis BCS;

$\omega_{y}$ is a component of $\mathbf{X}$ - angular rate around the $\mathrm{OY}$ - axis BCS;

$\omega_{Z}$ is a component of $\mathbf{X}$ - angular rate around the $\mathrm{OZ}$ - axis BCS;

$\varphi$ is a component of $\mathbf{X}$ - angle of rotation around the $\mathrm{OX}-$ axis of BCS;

$\vartheta$ is a component of $\mathbf{X}$ - angle of rotation around the $\mathrm{OY}$ - axis of BCS;

$\psi$ is a component of $\mathbf{X}$ - angle of rotation around the $\mathrm{OZ}$ - axis of BCS;

$X_{g}$ is a component of $\mathbf{X}$ - movement along the $\mathrm{OXg}$ - axis of GCS;

$Y_{g}$ is a component of $\mathbf{X}$ - movement along the $\mathrm{OYg}$ - axis of GCS;

$Z_{g}$ is a component of $\mathbf{X}$ - movement along the $\mathrm{OZg}$ - axis of GCS;

$\mathbf{X}_{m}$ is a measured state vector;

$V_{x m}$ is a component of $\mathbf{X}_{m}$ - measured linear speed along the $\mathrm{OX}$ - axis BCS;

$V_{y m}$ is a component of $\mathbf{X}_{m}$ - measured linear speed along the $\mathrm{OY}$ - axis BCS;

$V_{z m}$ is a component of $\mathbf{X}_{m}$ - measured linear speed along the $\mathrm{OZ}$ - axis $\mathrm{BCS}$;

$\omega_{x m}$ is a component of $\mathbf{X}_{m}-$ measured angular rate around the $\mathrm{OX}$ - axis BCS;

$\omega_{y m}$ is a component of $\mathbf{X}_{m}$ - measured angular rate around the $\mathrm{OY}$ - axis $\mathrm{BCS}$;

$\omega_{z m}$ is a component of $\mathbf{X}_{m}-$ measured angular rate around the $\mathrm{OZ}$ - axis $\mathrm{BCS}$;

$\varphi_{m}$ is a component of $\mathbf{X}_{m}$ - measured angle of rotation around the $\mathrm{OX}-$ axis of $\mathrm{BCS}$;

$\vartheta_{m}$ is a component of $\mathbf{X}_{m}$ - measured angle of rotation around the $\mathrm{OY}$ - axis of BCS; $\psi_{m}$ is a component of $\mathbf{X}_{m}$ - measured angle of rotation around the $\mathrm{OZ}$ - axis of BCS;

$X_{g m}$ is a component of $\mathbf{X}_{m}$ - measured movement along the $\mathrm{OXg}$ - axis of GCS;

$Y_{g m}$ is a component of $\mathbf{X}_{m}$ - measured movement along the OYg - axis of GCS;

$Z_{g m}$ is a component of $\mathbf{X}_{m}$ - measured movement along the $\mathrm{OZg}$ - axis of GCS;

$\mathbf{X}_{w}$ is a estimated state vector;

$V_{X w}$ is a component of $\mathbf{X}_{w}$ - estimated linear speed along the $\mathrm{OX}$ - axis BCS;

$V_{y w}$ is a component of $\mathbf{X}_{w}$ - estimated linear speed along the $\mathrm{OY}$ - axis BCS;

$V_{z w}$ is a component of $\mathbf{X}_{w}$ - estimated linear speed along the $\mathrm{OZ}$ - axis BCS;

$\omega_{X w}$ is a component of $\mathbf{X}_{w}$ - estimated $d$ angular rate around the $\mathrm{OX}$ - axis $\mathrm{BCS}$;

$\omega_{y w}$ is a component of $\mathbf{X}_{w}$ - estimated angular rate around the $\mathrm{OY}$ - axis BCS;

$\omega_{Z w}$ is a component of $\mathbf{X}_{w}$ - estimated angular rate around the $\mathrm{OZ}$ - axis BCS;

$\varphi_{w}$ is a component of $\mathbf{X}_{w}$ - estimated angle of rotation around the $\mathrm{OX}-$ axis of BCS;

$\vartheta_{w}$ is a component of $\mathbf{X}_{w}$ - estimated angle of rotation around the $\mathrm{OY}-$ axis of $\mathrm{BCS}$;

$\psi_{w}$ is a component of $\mathbf{X}_{w}$ - estimated angle of rotation around the $\mathrm{OZ}$ - axis of $\mathrm{BCS}$;

$X_{g w}$ is a component of $\mathbf{X}_{w}$ estimated movement along the $\mathrm{OXg}$ - axis of GCS;

$Y_{g w}$ is a component of $\mathbf{X}_{w}$ - estimated movement along the OYg - axis of GCS;

$Z_{g w}$ is a component of $\mathbf{X}_{w}$ - estimated movement along the $\mathrm{OZg}$ - axis of GCS;

$\Delta \mathbf{X}_{m}$ is a systematic error vector;

$\Delta V_{x m}$ is a component of $\Delta \mathbf{X}_{m}-$ systematic error of measured linear speed along the $\mathrm{OX}$ - axis BCS;

$\Delta V_{y m}$ is a component of $\Delta \mathbf{X}_{m}-$ systematic error of measured linear speed along the $\mathrm{OY}-$ axis BCS;

$\Delta V_{z m}$ is a component of $\Delta \mathbf{X}_{m}-$ systematic error of measured linear speed along the $\mathrm{OZ}-$ axis BCS;

$\Delta \omega_{x m}$ is a component of $\Delta \mathbf{X}_{m}-$ systematic error of measured angular rate around the $\mathrm{OX}$ - axis BCS;

$\Delta \omega_{y m}$ is a component of $\Delta \mathbf{X}_{m}-$ systematic error of measured angular rate around the $\mathrm{OY}$ - axis $\mathrm{BCS}$;

$\Delta \omega_{z m}$ is a component of $\Delta \mathbf{X}_{m}-$ systematic error of measured angular rate around the $\mathrm{OZ}$ - axis BCS;

$\Delta \varphi_{m}$ is a component of $\Delta \mathbf{X}_{m}-$ systematic error of measured angle of rotation around the $\mathrm{OX}$ - axis of BCS; 
$\Delta \vartheta_{m}$ is a component of $\Delta \mathbf{X}_{m}$ - systematic error of measured angle of rotation around the $\mathrm{OY}$ - axis of BCS;

$\Delta \psi_{m}$ is a component of $\Delta \mathbf{X}_{m}$ - systematic error of measured angle of rotation around the $\mathrm{OZ}$ - axis of BCS;

$\Delta X_{g m}$ is a component of $\Delta \mathbf{X}_{m}$ - systematic error of measured movement along the OXg - axis of GCS;

$\Delta Y_{g m}$ is a component of $\Delta \mathbf{X}_{m}$ - systematic error of measured movement along the OYg - axis of GCS;

$\Delta Z_{g m}$ is a component of $\Delta \mathbf{X}_{m}$ - systematic error of measured movement along the $\mathrm{OZg}-$ axis of GCS;

$\delta \mathbf{X}_{m}$ is a fluctuation error vector;

$\delta V_{x m}$ is a component of $\delta \mathbf{X}_{m}$ - fluctuation error of measured linear speed along the $\mathrm{OX}$ - axis BCS;

$\delta V_{y m}$ is a component of $\delta \mathbf{X}_{m}$ - fluctuation error of measured linear speed along the OY - axis BCS;

$\delta V_{Z m}$ is a component of $\delta \mathbf{X}_{m}$ - fluctuation error of measured linear speed along the $\mathrm{OZ}$ - axis BCS;

$\delta \omega_{x m}$ is a component of $\delta \mathbf{X}_{m}$ - fluctuation error of measured angular rate around the $\mathrm{OX}$ - axis BCS;

$\delta \omega_{y m}$ is a component of $\delta \mathbf{X}_{m}$ - fluctuation error of measured angular rate around the $\mathrm{OY}-$ axis BCS;

$\delta \omega_{z m}$ is a component of $\delta \mathbf{X}_{m}$ - fluctuation error of measured angular rate around the $\mathrm{OZ}$ - axis BCS;

$\delta \varphi_{m}$ is a component of $\delta \mathbf{X}_{m}$ - fluctuation error of measured angle of rotation around the $\mathrm{OX}$ - axis of BCS;

$\delta \vartheta_{m}$ is a component of $\delta \mathbf{X}_{m}$ - fluctuation error of measured angle of rotation around the OY - axis of BCS;

$\delta \psi_{m}$ is a component of $\delta \mathbf{X}_{m}$ - fluctuation error of measured angle of rotation around the $\mathrm{OZ}$ - axis of BCS;

$\delta X_{g m}$ is a component of $\delta \mathbf{X}_{m}$ - fluctuation error of

measured movement along the OXg - axis of GCS;

$\delta Y_{g m}$ is a component of $\delta \mathbf{X}_{m}$ - fluctuation error of measured movement along the OYg - axis of GCS;

$\delta Z_{g m}$ is a component of $\delta \mathbf{X}_{m}$ - fluctuation error of measured movement along the OZg - axis of GCS;

$\nabla \mathbf{X}_{m}$ is a failure error vector;

$\nabla V_{x m}$ is a component of $\nabla \mathbf{X}_{m}$ - failure error of measured linear speed along the OX - axis BCS;

$\nabla V_{y m}$ is a component of $\nabla \mathbf{X}_{m}$ - failure error of measured linear speed along the OY - axis BCS;

$\nabla V_{z m}$ is a component of $\nabla \mathbf{X}_{m}$ - failure error of measured linear speed along the $\mathrm{OZ}$ - axis BCS;

$\nabla \omega_{x m}$ is a component of $\nabla \mathbf{X}_{m}$ - failure error of measured angular rate around the $\mathrm{OX}$ - axis BCS;

$\nabla \omega_{y m}$ is a component of $\nabla \mathbf{X}_{m}$ - failure error of measured angular rate around the $\mathrm{OY}-$ axis BCS;

$\nabla \omega_{z m}$ is a component of $\nabla \mathbf{X}_{m}$ - failure error of measured angular rate around the $\mathrm{OZ}-$ axis $\mathrm{BCS}$; $\nabla \varphi_{m}$ is a component of $\nabla \mathbf{X}_{m}$ - failure error of measured angle of rotation around the $\mathrm{OX}$ - axis of BCS;

$\nabla \vartheta_{m}$ is a component of $\nabla \mathbf{X}_{m}$ - failure error of measured angle of rotation around the OY - axis of BCS;

$\nabla \psi_{m}$ is a component of $\nabla \mathbf{X}_{m}$ - failure error of measured angle of rotation around the $\mathrm{OZ}$ - axis of BCS;

$\nabla X_{g m}$ is a component of $\nabla \mathbf{X}_{m}$ - failure error of measured movement along the $\mathrm{OXg}$ - axis of GCS;

$\nabla Y_{g m}$ is a component of $\nabla \mathbf{X}_{m}$ - failure error of measured movement along the OYg - axis of GCS;

$\nabla Z_{g m}$ is a component of $\nabla \mathbf{X}_{m}$ - failure error of measured movement along the OZg - axis of GCS;

$\mathbf{W}$ is a vector of external influences from wind, current, waves;

$\mathbf{U}$ is a vector of controls;

$\mathbf{U}_{l}(\theta)$ is a component of $\mathbf{U}$ - linear motion control;

$\mathbf{U}_{a}(\delta)$ is a component of $\mathbf{U}$ - angular motion control;

$\theta$ is a telegraph deflection;

$\delta$ is a steering wheel deflection;

$\nabla \mathbf{U}_{l}$ is a vector of control deviations in case of failure in the linear channel;

$\nabla \mathbf{U}_{a}$ is a vector of control deviations in case of failure in the angulare channel;

$\mathbf{F}(\bullet)$ is a mathematical model of the control object;

$\mathbf{F}_{w}(\bullet)$ is a mathematical model of the observer;

$\mathbf{L}$ is an observer gain matrix;

$\Delta \mathbf{X}$ is a residual vector between the measured and estimated vectors;

$\Delta \mathbf{X}^{*}$ is a measurement tolerance vector;

$S W_{j}$ is a sign of $j$-sensor malfunction;

$n_{b}$ is a number of measurements in the control cycle;

$n_{f}$ is a number of erroneous measurements in control cycles;

$V^{*}$ is a required speed;

$K^{*}$ is a required course;

$\omega_{z} *$ is a required yaw rate;

$k_{\psi}$ is a yaw channel mismatch coefficient;

$k_{\omega}$ is a yaw rate mismatch coefficient;

$k_{\int}$ is a yaw channel mismatch integral coefficient;

$V_{\max }$ is a vessel's maximum speed.

\section{INTRODUCTION}

Currently, more than $90 \%$ of all cargo in the world is transported by sea. If we also take into account the presence of a significant number of warships, we can say that the oceans have become quite "crowded". People and their ship management decisions have caused most maritime accidents. Thus, the Dutch study "100 Sea casualties" revealed that the human factor led to 96 out of 100 accidents. According to the United Kingdom Protection 
and Indemnity Club, the human factor accounts for 89 $96 \%$ of ship collisions, $84-88 \%$ of tanker accidents, $79 \%$ of towing ship a grounds and costs the marine industry about \$ 541 million a year. A detailed analysis of the causes of ship accidents at sea due to the human factor is given in [1]. The human factor is the weakest link in ship management. Studies of the influence of the human factor on management have been considered in the works of many authors, in particular [1-5]. Organizational measures taken to strengthen the training and retraining of skippers, amending the International Convention on Standards of Training, Certification, and Watch keeping for Seafarers [1] in terms of language requirements, other measures did not lead to a significant reduction in accident rates. Experts note that the only way to achieve the desired result is the development and implementation of automated decision support systems and automatic control systems.

Automated decision support systems suggest a person in the control loop and provide him with technical support, for example, in the form of monitoring the parameters of the ship's state vector and propulsion system, the formation of warning messages, control warnings, etc. In such systems, despite the technical support from automated decision support systems, the skipper makes the final decision on the control of the ship, which means, in the control chain there remains the link of the HF with partially indefinite behavior that generates a certain percentage of errors and has large delays in the processing and transmission of information [6-7].

In automatic control systems, the HF link is absent, which gives them great advantages: automatic systems are not subject to fatigue, emotions, stresses; no communication problems; information in the system is transmitted almost without delay, which is especially important when controlled inertial dimensional objects; the task can be solved optimally, which saves time and resources. In automatic systems can be achieved greater control accuracy and reliability. The accuracy of control, in the absence of a HF link, is determined only by the errors of technical devices (sensors and actuators), the scheme and accuracy of the calculations. Using mathematical methods can improve the characteristics of the input signals and increase the accuracy of control.

The work [1] gives an example of a failure of the navigation equipment of the MS Royal Majesty ship. None of the crew found a failure of the equipment and did not even respond to the warning of the Portuguese fishing boats that the vessel was in danger, which ultimately led to the ship's departure from the route for 17 miles and landing aground. In automatic systems, incorrect operation or failure of navigation equipment, equipment in linear motion control channels (automation, engine, propulsion), angular movement control equipment (automation, drives, rudder) can be detected automatically by analyzing the dynamics of the control object. Most modern ships use autopilots, which are representatives of automatic systems. Similarly to autopilots, other automatic control modules can be developed that solve more complex ap- plied problems, for example, automatic divergence with many targets [8-9], automatic wiring in narrowness, optimal maneuvering, etc. The skipper, as in the case of autopilot, only makes a decision about the involvement of the necessary module and controls the implementation of the task, and technical control of the vessel is provided automatically, according to the algorithms laid down in the on-board controller. As follows from the foregoing, automatic control systems have huge advantages over manual control, as well as ADSS systems. Therefore, the development of such systems is an urgent scientific and technical task.

The object of research is the process of automatic vessel motion control in conditions of large deviations in sensors measurements during maneuvering and failures of sensors and actuators.

The subject of research is a method and algorithms for improving the accuracy and reliability of automatic vessel motion control systems in conditions of large deviations in sensors measurements during maneuvering and failures of sensors and actuators.

The aim of the research is development a method and algorithms for improving the accuracy and reliability of automatic vessel motion control systems in conditions of large deviations in sensors measurements during maneuvering and failures of sensors and actuators.

\section{PROBLEM STATEMENT}

Is given a mathematical model of the movement of the control object in the form of a system of nonlinear differential equations, taking into account the effects of wind, flow and waves, a mathematical model of actuators in the form of a system of linear differential equations with a model of errors and failures, as well as a mathematical model of sensors in the form of a system of algebraic equations with model of errors and failures.

$$
\begin{gathered}
\frac{d \mathbf{X}}{d t}=\mathbf{F}(\mathbf{X}, \mathbf{U})+\mathbf{W}, \\
\mathbf{X}_{m}=\mathbf{X}+\Delta \mathbf{X}_{m}+\delta \mathbf{X}_{m}+\nabla \mathbf{X}_{m}, \\
\mathbf{U}=\left(\mathbf{U}_{l}(\theta)+\nabla \mathbf{U}_{l}, \mathbf{U}_{a}(\delta)+\nabla \mathbf{U}_{a}\right) .
\end{gathered}
$$

It is required to form such controls $\theta$ and $\delta$ that would ensure control of the object (1) in conditions of measurement errors and failures of sensors (2) and actuators (3).

\section{LITERATURE REVIEW}

Article [10] investigated a model of the ship's dynamic positioning system by modeling real weather conditions in the laboratory, which allowed not only avoids the risks caused by direct experiments on a real ship, but also reduces the cost of the experiment. In order to implement high-precision positioning were used a highprecision mathematical model of the vessel and continuous position information with GPS. To improve positioning accuracy were analyzed the characteristics of many sensors, including radar, differential GPS, ultrasonic sen- 
sors, room temperature and others, followed by mathematical methods.

Article [11] considered the problems of wave filtration based on the Kalman filter, there were estimationd the noise covariance parameters, the Kalman filter was adjusted, using the obtained estimation, and its operation was verified in a dynamic positioning system by mathematical modeling.

Article [12] considered a new concept of navigation guidance, which allows to increase the reliability of the provided guidance on changing speed or course in automated decision support systems under conditions of incomplete information on the hydrodynamic model of the vessel and external influences.

Article [13] considered the issues of forecasting the movement of a vessel in a heeling channel. There was proposed an adaptive forecasting model as a combination of models with variable weights to improve the accuracy of forecasting and stability. To determine the weights there was used adaptive recursive identification.

Article [14] considered the issues of forecasting the movement of a vessel in maneuvering areas based on reference vectors. In contrast to forecasting methods based on an explicit mathematical model, there was built a black box model of a maneuvering ship. For the input values of the rudder and the variables of the state vector, as well as the output values of the hydrodynamic forces, there were identified complex nonlinear functions in the Abkowitz model, which were used to predict motion.

Article [15] considered the use of a mathematical model of full-circle propeller vessels for predicting their maneuverability. There was carried out propeller force analysis and synthesized the control of motion models. To test the effectiveness of the developed models and control algorithms, numerical modeling was carried out, the results of which are compared with field tests.

When creating modern aviation gas turbine engines, a significant complication of automatic control and monitoring systems is noted, which increases the probability of various violations in the measurement channel and complicates control tasks.

Article [16] considered the synthesis of a fault-tolerant flight control scheme based on a neural network. The proposed scheme involves diagnostics, fault detection and adaptation. The circuit was tested on an F-16 airplane model in case of drive failure.

As can be seen from the above review, the mathematical model of the control object was used to predict movement in control systems, including the ship, but there was not found Information about the methods:

- improving the reliability of ship control systems by detecting sensor failures in the channels of linear and angular movement of the control object according to the results of analysis of its movement dynamics;

- improving the reliability through parry failures of sensors by replacing their information (received from another sensor working in pair with a failure in one measurement channel, for example, if the linear speed sensor fails, its information can be replaced by position sensor information and vice versa, and if it fails the rotation speed sensor its information can be replaced by the information of the angular position sensor and vice versa);

- improving reliability by detecting failures of actuators based on the analysis of the dynamics of movement of the control object;

- improving accuracy when maneuvering the vessel by identifying unacceptable deviations of the sensors and replacing their information until the end of the maneuver (for example, during acceleration, braking, and turning the ship, the gyrocompass inertia deviates is present. During the maneuver, the gyrocompass date can be replaced by the rotation speed sensor in the jaw - channel).

\section{MATERIALS AND METHODS}

Figure 1 shows the block diagram of the control object and the control system.

The movement of the control object is presented in a $\mathrm{BCS}$, that moves relative to the GCS. The control object 1 moves under the action of external disturbances $\mathbf{W}$ and controls $\mathbf{U}_{l}, \mathbf{U}_{a}$ respectively in the linear and angular movement channels. The state vector parameters - the components of the speed $V_{x}, V_{y}, V_{z}$ and position vector $X_{g}, Y_{g}, Z_{g}$ are measured by a linear motion channel sensor 4.1 with an information processing period in the on-board controller. State vector parameters - the components of the rotation speed $\omega_{x}, \omega_{y}, \omega_{z}$ and angular position $\varphi, \theta, \psi$ are measured by the angular motion channel sensors 4.2 with the information processing period in the onboard controller. The measured parameters $V_{x m}, V_{y m}, V_{z m}, \quad \omega_{x m}, \omega_{y m}, \omega_{z m}, \quad \varphi_{m}, \theta_{m}, \psi_{m}$, $X_{g m}, Y_{g m}, Z_{g m}$ as well as the measured controls $\theta, \delta$ are input to the observer 7 . Observer 7 is a mathematical model of the control object and is used to estimate the state vector parameters of the control object. Due to the inaccuracy of the mathematical model and calculation errors, estimate of the state vector parameters with time will be more and more different from the state vector itself. To prevent this divergence, the observer's estimates are adjusted using the residuals between the measured parameters and their estimates.

$$
\frac{d \mathbf{X}_{w}}{d t}=\mathbf{F}_{w}\left(\mathbf{X}_{w}, \mathbf{U}\right)+\mathbf{L}\left(\mathbf{X}_{m}-\mathbf{X}_{w}\right)
$$

In comparator 9, the measured state vector parameters $\mathbf{X}_{m}$ are compared at each step of the calculations with the corresponding estimation vector parameters $\mathbf{X}_{w}$ to form the residual vector $\Delta \mathbf{X}=\mathbf{X}_{m}-\mathbf{X}_{w}$, which is fed to the fault diagnosis unit 10 .

The fault diagnosis unit 10 controls the excess of the residual vector parameters $\Delta \mathbf{X}$ the permissible values $\Delta \mathbf{X}^{*}$. 


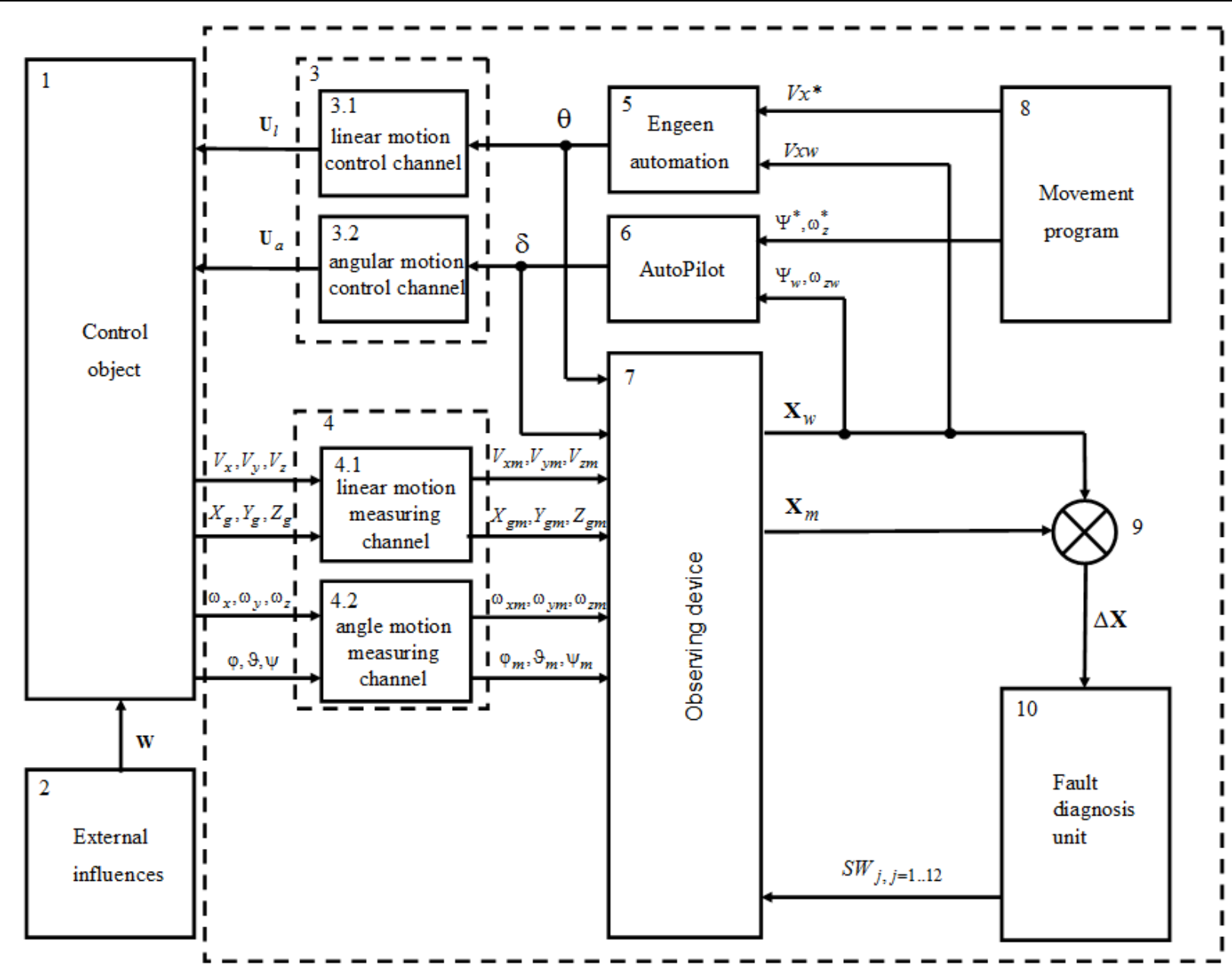

Figure 1 - The block diagram of the control object and the control system

If one of the parameters $\Delta \mathbf{X}_{j}$ exceeds the permissible value $\Delta \mathbf{X}_{j}{ }^{*}$, the failure diagnosis unit 10 feeds to the input of the observer 7 a signal $S W_{j}=0$ to reset the $j-$ column of the matrix $\mathbf{L}$ in order to prevent distortion of the state vector estimates by the $j-$ sensor. In this case, a further estimate of the state vector $\mathbf{X}_{w}$ is made according to the replacement information. Replacement information is the information of another sensor, operating in the same measurement channel, for example, speed and position sensors work in a linear motion channel and can replace each other when one of them failed, and angular rate sensor and angular position sensor also work in one channel angular motion and can replace each other when one of them failed.

The fault diagnosis unit 10 monitors the dates of the $j$ - sensor, as well as other sensors, at each control interval $n_{b}$. If the number of unreliable measurements $n_{f}=0$ during the control interval $n_{b}$, the failure diagnosis unit 10 returns $S W_{j}=1$, otherwise $S W_{j}=0$. If at the same time or sequentially, after a short time interval, the fault diagnosis unit 10 detects a failure of the main and replacement sensors, then this is regarded as a failure in the control channel in which the failures of the main and replacement sensors were detected. For example, a simultaneous or sequential failure of the speed sensor and the position sensor in the linear motion channel is regarded as the failure of the linear control channel (engine, propulsion device, amplifiers, automation or any other device whose failure can violate the relationship between the screw force and telegraph position). Also, the simultaneous or sequential failure of the main and replacement sensors in the angular motion channel is regarded as a failure in the angular control channel (steering wheel, drive, amplifiers, automation, or any other device whose failure can violate the relationship between the control moment and the position of the steering wheel).

Estimations of the yaw angle $\psi_{w}$ and yaw rate $\omega_{z w}$ from the output of the observer 7 , as well as the required course $K^{*}$ and the required yaw rate $\omega_{z}^{*}$, from the block of motion programs 8 , are fed to the inputs of the autopilot 6 , where control $\delta$ is formed

$$
\begin{aligned}
& \delta=k_{\psi}\left(\psi_{w}-K^{*}\right)+k_{\omega}\left(\omega_{z w}-\omega_{z}{ }^{*}\right)+ \\
& +k_{\int} \int\left(\psi_{w}-K^{*}\right) d t .
\end{aligned}
$$


The speed estimation Vxw from the output of the observer 7 , as well as the required speed $V_{X}{ }^{*}$ from the block of motion programs 8 are fed to the inputs of engine automation unit 5 , where control $\theta$ is formed

$$
\theta=\frac{\pi}{2} \frac{V_{x}^{*}}{V_{\max }}
$$

\section{EXPERIMENTS}

Verification of the operability and effectiveness of the method and algorithms for improving the accuracy and reliability of automatic vessel motion control systems in conditions of large deviations in sensors measurements during maneuvering and failures of sensors and actuators, as well as the mathematical support developed on its basis, was verified by mathematical modeling in the MATLAB environment of a control object in a closed circuit with a control system including an observer and a fault diagnosis unit.

During all experiments, the following measurement errors were adopted:

- linear speeds: systematic $\Delta V_{x m}, \Delta V_{y m}, \Delta V_{z m}=0.5$ $\mathrm{m} / \mathrm{s}$, fluctuation $\delta V_{x m}, \delta V_{y m}, \delta V_{z m}=0.21 \mathrm{~m} / \mathrm{s}$;

- positon: systematic $\Delta X_{g}, \Delta Y_{g}, \Delta Z_{g}=10 \mathrm{~m} / \mathrm{s}$, fluctuation $\delta X_{g}, \delta Y_{g}, \delta Z_{g}=5 \mathrm{~m} / \mathrm{s}$;

- angular rate: systematic $\Delta \omega_{x m}, \Delta \omega_{y m}, \Delta \omega_{z m}=0.002$ $\mathrm{dg} / \mathrm{s}$, fluctuation $\delta \omega_{x m}, \delta \omega_{y m}, \delta \omega_{z m}=0.002 \mathrm{dg} / \mathrm{s}$;

- angular position: systematic $\Delta \varphi_{m}, \Delta \theta_{m}, \Delta \psi_{m}=1 \mathrm{dg}$, fluctuation $\delta \varphi_{m}, \delta \theta_{m}, \delta \psi_{m}=1 \mathrm{dg}$;

Fig. 2 shows the results of detecting sensor failures during acceleration of the vessel and simultaneous yaw turning on $45 \mathrm{dg}$.

The graphs are shown (vertically):

- measured speed $V_{x m}$, yaw angle $\psi_{m}$ and position $Y_{g m}$
- estimated speed $V_{x w}$, yaw angle $\psi_{w}$ and position $Y_{g w}$; - matrix gain coefficients $\mathbf{L}$ for measurements $V_{x m}, \psi_{m}, Y_{g m}$.

For $50 \mathrm{~s}, 70 \mathrm{~s}$ and $20 \mathrm{~s}$ were simulated respectively a failure error of measured linear speed $V_{x m}$, measured yaw angle $\psi_{m}$, and measured position $Y_{g m}$. Inadmissible deviations of measured linear speed, measured yaw angle and measured position from their estimations were revealed. To exclude the influence of unacceptable deviations of the sensors on the estimations, the matrix gains for these measurements are zeroed. After restoration of the sensors, the gain is restored.

Fig, 3 shows results of detection and parry linear speed sensor failure during acceleration of the vessel from zero speed to maximum.

The graphs are shown (horizontally):

- linear speed $V_{X}$, measured speed $V_{x m}$, estimated speed $V_{x w}$

- movement $X_{g}$, measured movement $X_{g m}$, estimated movement $X_{g w}$;

- matrix gain coefficients lmd (1) for measured speed $V_{x m}$ and lmd (10) for measured movement $X_{g m}$ as well as telegraph deflection $\theta$.

For $50 \mathrm{~s}$ was simulated linear speed sensor failure. As can be seen from the simulation results, this failure was detected and parried (matrix gain coefficients lmd (1) was reset to zero and further estimation $V_{X w}$ was carried out only by measurements $X_{g m}$ of the replacement sensor).

Fig. 4 shows results of detection and parry yaw angle sensor failure during a turn of the vessel at angle of 45 degrees

The graphs are shown (horizontally):

- yaw rate $\omega_{z}$, measured yaw rate $\omega_{z m}$, estimated yaw rate $\omega_{z w}$;
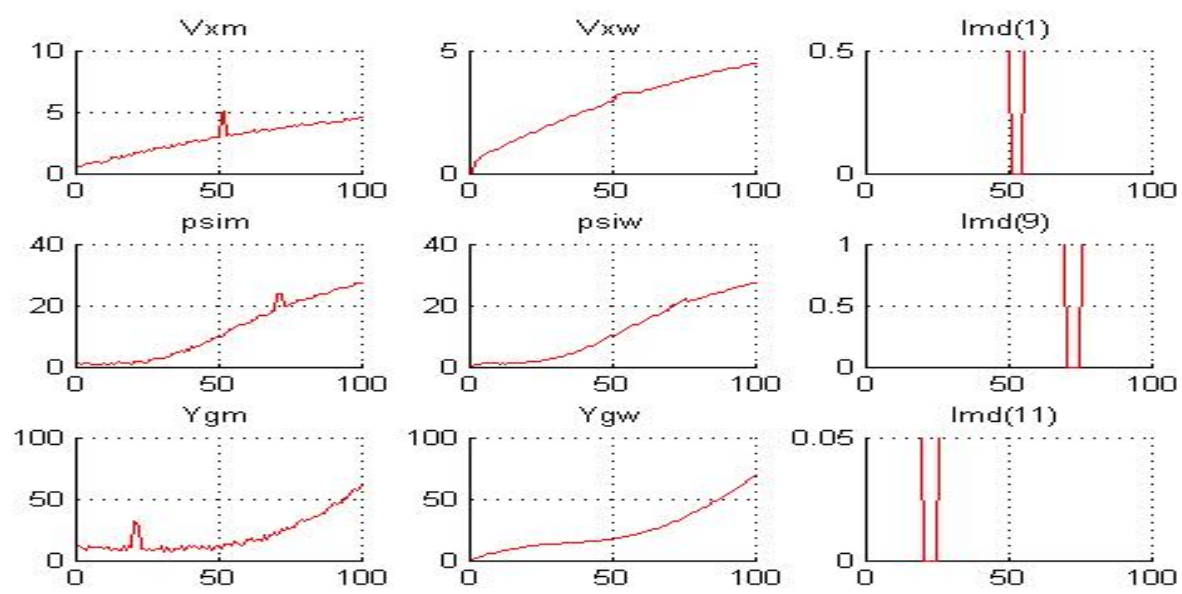

Figure 2 - The results of detecting sensor failures 

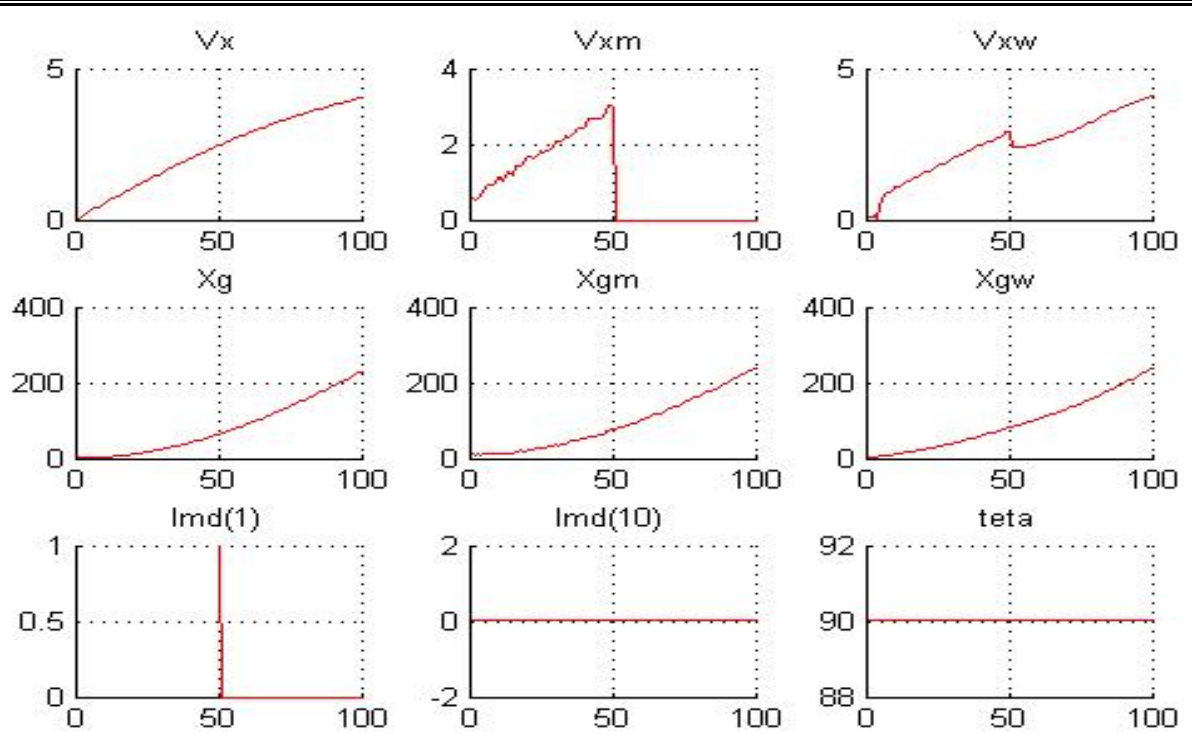

Figure 3 - Detection and parry linear speed sensor failure
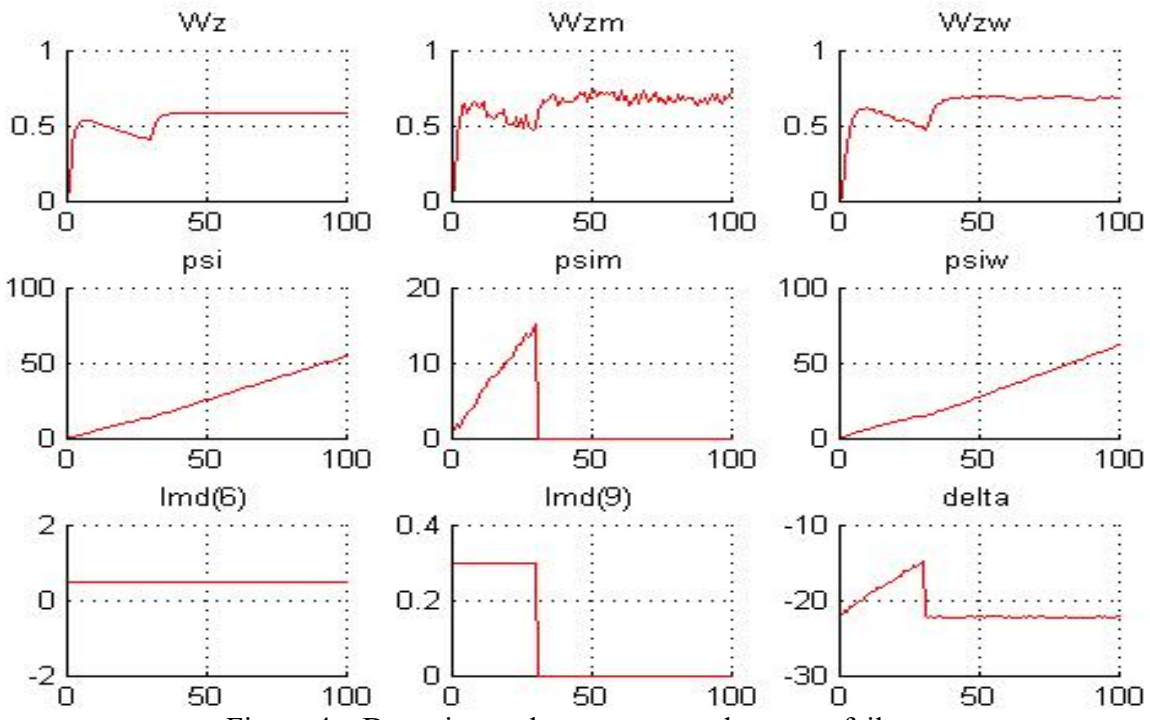

Figure 4 - Detection and parry yaw angle sensor failure

- yaw angle $\psi$, measured yaw angle $\psi_{m}$, estimated yaw angle $\psi_{w}$;

- matrix gain coefficients lmd (6) for measured yaw rate $\omega_{z m}$ and lmd (9) for measured yaw angle $\psi_{m}$ as well as the steering wheel deflection $\delta$.

For $30 \mathrm{~s}$ was simulated the yaw angle sensor failure. As can be seen from the simulation results, this failure was detected and parried (matrix gain coefficients lmd (9) was reset to zero and further estimation $\psi_{w}$ was carried out only by measurements $\omega_{z m}$ of the replacement sensor.

Fig. 5 shows the results of detection linear motion control channel failure, when the vessel was moving at maximum speed. The graphs are shown (horizontally):

- linear speed $V_{X}$, measured linear speed $V_{x m}$, estimated linear speed $V_{X W}$;
- movement $X_{g}$, measured movement $X_{g m}$, estimated movement $X_{g w}$;

- matrix gain coefficients lmd (1) for measured linear speed $V_{x m}$ and lmd (10) for measured movement $X_{g m}$ as well as the telegraph deflection $\theta$.

For $50 \mathrm{~s}$ the engine failure was simulated (the screw force does not correspond to the telegraph deflection $\theta$ ). As can be seen from the simulation results, this failure manifested itself through the failures of both sensors linear speed sensor and movement sensor. Since the probability of simultaneous failure of two sensors is small, it was diagnosed not a sensors failure but linear motion control channel failure (engine, propulsion device, amplifiers, automation, or any other device, the failure of which may violate the relationship between the screw force and telegraph deflection $\theta$ ).

Fig. 6 shows the results of detection of angle motion control channel failure, when the vessel turns 45 degrees. 

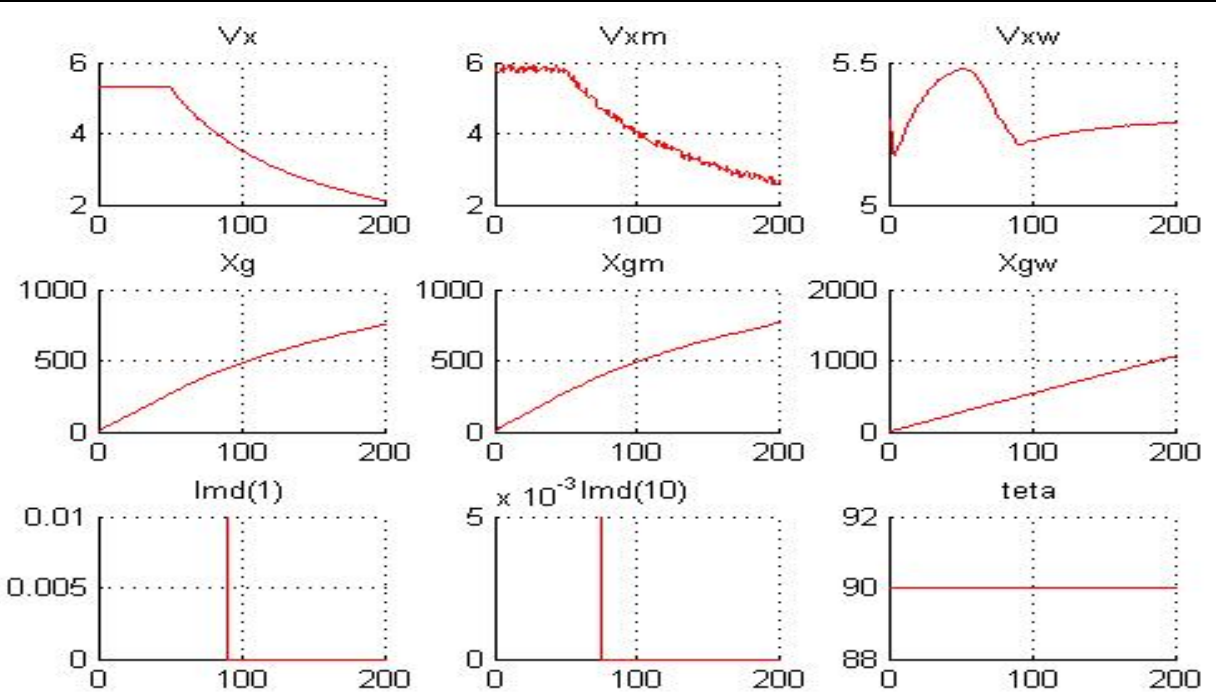

Figure 5 - Detection linear motion control channel failure
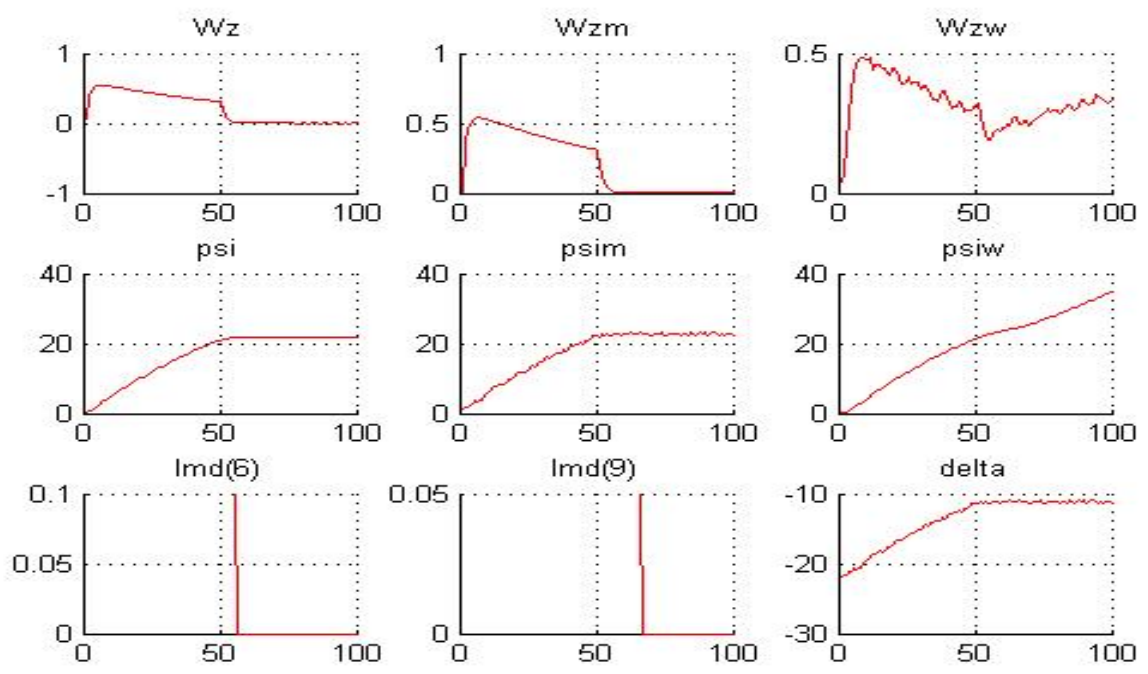

Figure 6 - Detection of angle motion control channel failure

For $50 \mathrm{~s}$ the engine failure was simulated (the screw force does not correspond to the telegraph deflection $\theta$ ). As can be seen from the simulation results, this failure manifested itself through the failures of both sensors linear speed sensor and movement sensor. Since the probability of simultaneous failure of two sensors is small, it was diagnosed not a sensors failure but linear motion control channel failure (engine, propulsion device, amplifiers, automation, or any other device, the failure of which may violate the relationship between the screw force and telegraph deflection $\theta$ ).

The graphs are shown (horizontally):

- yaw rate $\omega_{z}$, measured yaw rate $\omega_{z m}$, estimated yaw rate $\omega_{z w}$;

- yaw angle $\psi$, measured yaw angle $\psi_{m}$, estimated yaw angle $\psi_{w}$;

- matrix gain coefficients lmd (6) for measured yaw rate $\omega_{z m}$ and $1 \mathrm{md}$ (9) for measured yaw angle $\psi_{m}$ as well as the steering wheel deflection $\delta$.
For $50 \mathrm{~s}$ simulated failure in the channel of angular motion (the control moment does not correspond to the steering wheel deflection $\delta$ ). As can be seen from the simulation results, this failure manifested itself through the failures of both sensors - yaw rate sensor and yaw sensor. Since the probability of simultaneous failure of two sensors is small, it was diagnosed not a sensors failure but angular motion control channel failure (ruder, drive, amplifiers, automation, or any other device, the failure of which may violate the relationship between the control moment and the position of the steering wheel).

\section{RESULTS}

There were considered the issues of improving the accuracy and reliability of automatic vessel motion control systems in conditions of large deviations in sensors measurements during maneuvering and failures of sensors and actuators. There were analyzed the existing methods of increasing the accuracy and reliability of control in automatic systems, their shortcomings was identified and the relevance of solving this problem was substantiated. 
There were developed the method and algorithms for improving the accuracy and reliability of automatic vessel motion control systems in conditions of large deviations in sensors measurements during maneuvering and failures of sensors and actuators. The effectiveness of the proposed method and algorithms were verified by mathematical modeling of the control object in a closed circuit with a control system in the MATLAB environment for various types of ships, navigation areas, weather conditions and cases of large deviations in sensors measurements during maneuvering and failures of sensors and actuators.

\section{DISCUSSION}

They were proposed the method and algorithms of the vessel linear and angular motion control system, which allow to increase the accuracy and reliability of control in the conditions of significant errors of the sensors during intensive maneuvering and possible failures of the sensors and actuators.

As can be seen from the results of mathematical modeling (Fig. 1 - Fig. 6), the proposed method and algorithms, in comparison with the known solutions [1016], make it possible to detect and parry the failures of sensors and actuators in the channels of linear and angular movement of the vessel due to the use of an observer in the control system for assessing the parameters of the state vector by measuring the parameters of motion, constant monitoring of the measured information according to the estimates of state vector parameters, forming a failure of the sensor that did not pass the control, and replacing its data with the information of another sensor working with it in pair.

The failure of actuators in the control channel is detected if a simultaneous or sequential, after a short period of time, failure of the main and replacement sensors of this channel is detected.

The proposed method and algorithms can be used in the development of software for automatic vessel motion control systems.

\section{CONCLUSIONS}

There were proposed a method and algorithms to improve the accuracy and reliability of the automatic vessel control systems.

The scientific novelty of the obtained results consists in the fact that for the first time were proposed a method and algorithms for improving the accuracy and reliability of the automatic vessel control systems working in conditions of large deviations in sensors measurements during maneuvering and failures of sensors and actuators.

This is achieved by using in onboard controller of the automatic vessel motion control systems an observer to estimation the parameters of the state vector in the linear motion channel by measurements of linear speed and position sensors; estimation the parameters of the state vector in the angular motion channel by measurements of rotational speed and angular position sensors; continuous monitoring of the measured information by comparing it with the obtained estimations; correction estimations in the linear motion channel by measurements of linear speed and position sensors that have passed control; correction estimations in the angular motion channel by measurements of rotational speed and angular position sensors that have passed control; formation of a sensor failure in the linear motion channel (linear speed sensor or position sensor), if its measurements differ from the corresponding estimations for a greater than permissible value, to parry the failure in the linear motion channel by disconnecting the failed sensor from the observer and further estimation according to another sensor working in pairs; formation of a sensor failure in the angular motion channel (rotation speed sensor or angular position sensor), if its measurements differ from the corresponding estimations for a greater than permissible value, to parry the failure in the angular motion channel by disconnecting the failed sensor from the observer and further estimation according to another sensor working in pair; formation of an actuators failure in the linear motion channel (engine, automation or other device) if a simultaneous or sequential failure of both sensors were detected - linear speed sensor and position sensor, actuator failure alarm in the linear motion channel; formation of an actuators failure in the angular motion channel (rudders, drives, other devices) if a simultaneous or sequential failure of both sensors were detected - rotation speed sensor and angular position sensor, actuator failure alarm in the angular motion channel. This method and algorithms make it possible to improve the accuracy and reliability of automatic vessel motion control processes in conditions of large deviations in sensors measurements during maneuvering and failures of sensors and actuators. The proposed method and algorithms for improving the accuracy and reliability of automatic vessel motion control systems in conditions of large deviations in sensors measurements during maneuvering and failures of sensors and actuators were verified by mathematical modeling in the MATLAB environment of the control object movement in a closed circuit with a control system for various types of vessels, navigation areas, weather conditions and cases of large deviations in sensors measurements during maneuvering and failures of sensors and actuators.

The practical value of the obtained results lies in the fact that the developed method and algorithms were tested by mathematical modeling in the MATLAB environment of the control object movement in a closed circuit with a control system for various types of vessels, navigation areas, weather conditions and cases of large deviations in sensors measurements during maneuvering and failures of sensors and actuators.

Mathematical modeling confirmed the efficiency of the developed method and algorithms and allows to recomend them for practical use in the development of mathematical support of vessel motion control systems.

Further research may be related to the development of methods and algorithms that increase the reliability of fault detection and prediction accuracy. 


\section{ACKNOWLEDGEMENTS}

The work was carried out in the framework of the research "Development of software solutions for dynamic functions of dynamically positioning systems of marine vessels", (state registration number 0119U100948), Department of Navigation and Electronic Navigation Systems of Kherson State Maritime Academy.

\section{REFERENCES}

1. Apostol-Mates R., Barbu A. Human error - the main factor in marine accidents, Naval Academy Scientific Bulletin, 2016, Vol. 19, Issue 2. DOI: 10.21279/1454-864X-16-I2-068

2. Sotiralis P. N. Ventikos P., Hamann R., Golyshev P., Teixeira A. P. Incorporation of human factors into ship collision risk models focusing on human centred design aspects, Reliability Engineering \& System Safety. - 2016. - Vol. - 156. - P. 210 227. DOI: $10.1016 /$ j.ress.2016.08.007

3. Luo M., Shin S. Half-century research developments in maritime accidents: Future directions, Accident Analysis \& Prevention, 2019, Vol. 123, pp. 448-460. DOI: 10.1016/j.aap.2016.04.010

4. Popovych I. S., Blynova O. Ye, Aleksieieva M. I., Nosov P. S. Zavatska N. Ye., Smyrnova O. O. Research of Relationship between the Social Expectations and Professional Training of Lyceum Students studying in the Field of Shipbuilding, Revista Espacios, 2019, Vol. 40, Issue 33, pp. 21-34.

5. Popovych I. Psychology of Social Expectations of Personality: Methodology, Theory and Practice [Electronic resource], Revista ESPACIOS, 2019, Vol. 40(33), P. 21. Access mode: https://www.revistaespacios.com/a19v40n33/19403321.html

6. Nosov P. S., Ben A. P., Mateichuk V. N., Safonov M. S. Identification of "Human error" negative manifestation in maritime transport, Radio Electronics, Computer Science, Control, 2018, Vol. 4 (47), pp. 204-213. DOI: 10.15588/1607-3274-2018-4-20

7. Nosov P., Ben A., Safonova A., Palamarchuk I. Approaches going to determination periods of the human factor of navigators during supernumerary situations, Radio Electronics, Computer Science, Control, 2019, Vol. 2(49), pp. 140-150. DOI: 10.15588/1607-3274-2019-2-15

8. Zinchenko S. M., Nosov P. S., Mateichuk V. M., Mamenko P. P., Grosheva O. O. Automatic collision avoidance with many targets, including maneuvering ones, Radio Electronics, Computer Science, Control, 2019, Vol. 4, pp. 211 - 222. DOI: 10.15588/1607-3274-2019-4-20

9. Zinchenko S., Nosov P., Mateichuk V., Mamenko P., Grosheva O. Automatic collision avoidance with many targets, including maneuvering ones, The International scientific and practical conference dedicated to the memory of professor Fomin Y. Y. and Semenov V. S. (FS-2019). Odessa - Istanbul - Odessa, 2428 April, 2019, proceedings, ONMU, 2019, pp. 343-349.

10. Xiong J., Shu L., Wang Q., Xu W., Zhu Ch. A Scheme on Indoor Tracking of Ship Dynamic Positioning Based on Distributed Multi-Sensor Data Fusion, IEEE Access, 2016, Vol. 5, pp. 379-392. DOI: 10.1109/ACCESS.2016.2607232

11. Fossen T. I., Perez T. Kalman filtering for positioning and heading control of ships and offshore rigs, IEEE Control Systems Magazine, 2009, Vol. 29, Issue 6, pp. 32-46. DOI: 10.1109/MCS.2009.934408

12. Nielsen U. D., Jensen J. A novel approach for navigational guidance of ships using onboard monitoring systems, Ocean Engineering, 2011,Vol. 38, Issues 2-3, pp. 444-455. DOI: 10.1016/j.oceaneng.2010.11.024

13. Peng X., Zhang B., Rong L. Ship motion prediction of combination forecasting model based on adaptive variable weight, 34th Chinese Control Conference (CCC), 28-30 July, 2015: proceedings. Hangozhou, China (Lecture Notes in IEEE Xplore, 2015). DOI: 10.1109/ChiCC.2015.7260259

14. Luo W., Zou Z. Blind Prediction of Ship Maneuvering by Using Support Vector Machines, 29th International Conference on Ocean, Offshore and Arctic Engineering (ASME 2010), 6-11 June, 2010: proceeding. Shanghai, Chaina (Lecture Notes in American Society of Mechanical Engineers, 2010, pp. 437 443). DOI: 10.1115/OMAE2010-20723

15. Wu X., Gao X. Maneuverability prediction for a ship with fullrevolving twin propellers, Chinese Journal of Ship Research, 2017, Vol. 12, Issue 1, DOI: 10.3969/j.issn.16733185.2017.01.005

16. Chen Y. M., Lee M. L. Neural networks-based scheme for system failure detection and diagnosis, Mathematics and Computers in Simulation, 2002, Vol. 58, Issue 2, pp. 101-109. DOI: 10.1016/S0378-4754(01)00330-5

Received 23.01.2020. Accepted 22.02.2020.

\section{УДК 004.942:656.61.052}

\section{ПІДВИЩЕННЯ ТОЧНОСТІ ТА НАДІЙНОСТІ АВТОМАТИЧНИХ СИСТЕМ КЕРУВАННЯ РУХОМ СУДНА}

Зінченко С. М. - канд. техн. наук, старший викладач кафедри управління судном, завідувач лабораторії електронних тренажерів, Херсонська державна морська академія, Херсон, Україна.

Бень А. П. - канд. техн. наук, професор кафедри судноводіння та електронних навігаційних систем, проректор 3 науково-педагогічної роботи, Херсонська державна морська академія, Херсон, Україна.

Носов П. С. - канд. техн. наук, доцент кафедри судноводіння та електронних навігаційних систем, Херсонська державна морська академія, Херсон, Україна

Попович I. С. - д-р псих. наук, професор кафедри загальної та соціальної психології, Херсонський державний університет, Херсон, Україна.

Маменко П. П. - капітан далекого плавання, старший викладач кафедри управління судном, Херсонська державна морська академія, Херсон, Україна.

Матейчук В. М. - старший викладач кафедри управління судном, завідувач лабораторії електронних тренажерів, Херсонська державна морська академія, Херсон, Україна.

\section{АНОТАЦЯ}

Актуальність. Розглянуті питання підвищення точності і надійності систем автоматичного керування рухом судна при значних відхиленнях вимірюваної сенсорами інформації у процесі маневрування судна та при відмовах сенсорів і виконуючих пристроїв. Об'єктом дослідження є процес автоматичного керування рухом судна при значних відхиленнях вимірюваної сенсорами інформації у процесі маневрування судна та при відмовах сенсорів і виконуючих пристроїв. Суб'єктом дослідження є метод і алгоритми підвищення точності і надійності систем автоматичного керування рухом судна при значних відхиленнях вимірюваної сенсорами інформації у процесі маневрування судна та при відмовах сенсорів і виконуючих пристроїв. 
Мета. Метою дослідження є розробка методу та алгоритмів підвищення точності і надійності систем автоматичного керування рухом судна при значних відхиленнях вимірюваної сенсорами інформації у процесі маневрування судна та при відмовах сенсорів і виконуючих пристроїв.

Метод. Ця мета досягається за рахунок використання у бортовому контролері системи автоматичного керування рухом судна оцінювача параметрів вектору стану у каналі лінійного руху по даним вимірювання лінійної швидкості і переміщення; оцінювання параметрів вектору стану у каналі кутового руху по даним вимірювання кутової швидкості і переміщення, постійного контролю за достовірністю вимірюваної інформації шляхом іiї порівняння з отриманими оцінками параметрів вектору стану; коригування оцінок у каналі лінійного руху по виміряним сенсорами даним лінійної швидкості і лінійного переміщення, що пройшли перевірку; коригування оцінок у каналі кутового руху по виміряним сенсорами даним кутової швидкості і кутового переміщення, що пройшли перевірку; формування відмови датчика у каналі лінійного руху (датчика лінійної швидкості або датчика лінійного переміщення), якщо його вимірювання відрізняються від оцінок на величину більшу допустимої, парирування відмови датчика у каналі лінійного руху шляхом його відключення від оцінювача та подальшого оцінювання по інформації іншого датчика, що працює з ним у парі; формування відмови датчика у каналі кутового руху (датчика кутової швидкості або датчика кутового положення), якщо його вимірювання відрізняються від оцінок на величину більшу допустимої, парирування відмови датчика у каналі кутового руху шляхом його відключення від оцінювача та подальшого оцінювання параметрів по інформації іншого датчика, що працює 3 ним у парі; формування відмови по управлінню у каналі лінійного руху (силової установки, автоматики або іншого виконуючого пристрою), якщо одночасно, або послідовно, через невеликий проміжок часу, зафіксована відмова обох датчиків (лінійної швидкості і лінійного переміщення), формування алярму про відмову управління у каналі лінійного руху; формування відмови по управлінню у каналі кутового руху (керма, приводів, інших виконуючих пристроїв), якщо одночасно або послідовно, через невеликий проміжок часу, зафіксовано відмову обох датчиків (кутової швидкості і кутового переміщення), формування алярму у каналі управління кутовим рухом. Даний метод та алгоритми дозволяють підвищити точність та надійність автоматичної системи керування рухом судна при значних відхиленнях вимірюваної сенсорами інформації у процесі маневрування та при відмовах сенсорів і виконуючих пристроїв.

Результати. Запропонований метод і алгоритми підвищення точності і надійності систем автоматичного керування рухом судна були перевірені математичним моделюванням у середовищі MATLAB процесів керування рухом судна у замкнутій схемі із системою керування для різних типів суден, районів плавання, погодних умов, випадків значних відхилень вимірюваної інформації при маневруваннях та відмов сенсорів і виконуючих пристроїв.

Висновки. Результати проведеного математичного моделювання підтвердили працездатність та ефективність запропонованого метода і алгоритмів та дозволяють рекомендувати їх для практичного використання при розробці математичного забезпечення бортових контролерів систем автоматичного керування рухом суден, що працюють в умовах значних відхилень вимірюваної інформації у процесі маневрування та в умовах відмов сенсорів і виконуючих пристроїв..

КЛЮЧОВІ СЛОВА: парирування відмов обладнання, оцінювач, підвищення точності і надійності управління, математична модель, бортовий комп’ютер, оцінювання вектору стану, сенсор, виконуючий пристрій.

\section{УДК 004.942:656.61.052}

\section{ПОВЫШЕНИЕ ТОЧНОСТИ И НАДЕЖНОСТИ АВТОМАТИЧЕСКИХ СИСТЕМ УПРАВЛЕНИЯ ДВИЖЕНИЕМ}

\section{СУДНА}

Зинченко С. Н. - канд. техн. наук, старший преподаватель кафедры управления судном, заведующий лабораторией электронных тренажеров, Херсонская государственная морская академия, Херсон, Украина.

Бень А. П. - канд. техн. наук, профессор кафедры судовождения и электронных навигационных систем, проректор по научно-педагогической работе, Херсонская государственная морская академия, Херсон, Украина.

Носов П. С. - канд. техн. наук, доцент кафедры судовождения и электронных навигационных систем, Херсонская государственная морская академия, Херсон, Украина.

Попович И. С. - д-р псих. наук, профессор кафедры общей и социальной психологи, Херсонский государственный университет, Херсон, Украина.

Маменко П. П. - капитан дальнего плавания, старший преподаватель кафедры управления судном, Херсонская государственная морская академия, Херсон, Украина.

Матейчук В. Н. - старший преподаватель кафедры управления судном, заведующий лабораторией электронных тренажеров, Херсонская государственная морская академия, Херсон, Украина.

\section{АННОТАЦИЯ}

Актуальность. Рассмотрены вопросы повышения точности и надежности систем автоматического управления движением судна в условиях повышенных ошибок измерений при маневрировании и отказов сенсоров и исполнительных устройств. Объектом исследования является процесс автоматического управления движением судна в условиях повышенных ошибок измерений при маневрировании и отказов сенсоров и исполнительных устройств. Субъектом исследования является метод и алгоритмы повышения точности и надежности систем автоматического управления движением судна в условиях повышенных ошибок измерений при маневрировании и отказов сенсоров и исполнительных устройств.

Цель. Целью исследования является разработка метода и алгоритмов повышения точности и надежности систем автоматического управления движением судна в условиях повышенных ошибок измерений при маневрировании и отказов сенсоров и исполнительных устройств.

Метод. Эта цель достигается за счет использования в бортовом контроллере системы автоматического управления движением судна наблюдающего устройства для оценки параметров вектора состояния в канале линейного движения по данным измерений линейной скорости и перемещения; оценивания параметров вектора состояния в канале углового движения по данным измерений угловой скорости и углового перемещения, постоянного контроля за достоверностью измеряемой 
информации путем ее сравнения с полученными оценками параметров вектора состояния; корректировки оценок в канале линейного движения по измерениям линейной скорости и линейного перемещения, которые прошли контроль; корректировки оценок в канале углового движения по измеряниям угловой скорости и углового перемещения, которые прошли контроль; формирование отказа датчика в канале линейного движения (датчика линейной скорости или датчика линейного перемещения), если его измерения отличаются от оценок на величину, большую допустимой, парирование отказа датчика в канале линейного движения путем его отключения от наблюдателя и дальнейшего оценивания по информации другого датчика, что работает с ним в паре; формирование отказа датчика в канале углового движения (датчика угловой скорости или датчика углового перемещения), если его измерения отличаются от оценок на величину, большую допустимой, парирование отказа датчика в канале углового движения путем его отключения от наблюдателя и дальнейшего оценивания по информации другого датчика, что работает с ним в паре; формирование отказа по управлению в канале линейного движения (силовой установки, автоматики или другого исполнительного устройства), если одновременно или последовательно, через небольшой промежуток времени, выявлены отказы обеих датчиков (линейной скорости и линейного перемещения), формирование аларма об отказе управления в канале линейного движения; формирование отказа по управлению в канале углового движения (руля, приводов, автоматики или другого исполнительного устройства), если одновременно или последовательно, через небольшой промежуток времени, выявлены отказы обеих датчиков (угловой скорости и углового перемещения), формирование аларма об отказе управления в канале углового движения. Данный метод и алгоритмы позволяют повысить точность и надежность систем автоматического управления движением судна в условиях повышенных ошибок измерений при маневрировании и отказов сенсоров и исполнительных устройств.

Результати. Предложенный метод и алгоритмы повышения точности и надежности систем автоматического управления движением судна были проверены математическим моделированием в среде MATLAB процессов управления движением судна для различных типов судов, районов плавання, погодних условий, случаев повышенных ошибок измерений при маневрировании и отказов сенсоров и исполнительных устройств.

Выводы. Результаты проведенного математического моделирования подтверждают работоспособность и эффективность предложенного метода и алгоритмов и позволяют рекомендовать их для практического использования при разработке математического обеспечения бортовых контроллеров систем автоматического управления движением судов, которые работают в условиях повышенных ошибок измерений при маневрировании и отказов сенсоров и исполнительных устройств.

КЛЮЧЕВЫЕ СЛОВА: парирование отказов оборудования, наблюдатель, повышение точности и надежности управления, математическая модель, бортовой контроллер, оценка вектора состояния, сенсор, исполнительное устройство.

\section{ЛІТЕРАТУРА / ЛИТЕРАТУРА}

1. Apostol-Mates R. Human error - the main factor in marine accidents / R. Apostol-Mates, A. Barbu // Naval Academy Scientific Bulletin. - 2016. - Vol. 19. - Issue 2. DOI: 10.21279/1454-864X-16-I2-068

2. Incorporation of human factors into ship collision risk models focusing on human centred design aspects / [P. Sotiralis, N. P Ventikos, R. Hamann, et all] // Reliability Engineering \& System Safety. - 2016. - Vol. - 156. - P. 210-227. DOI: 10.1016/j.ress.2016.08.007

3. Luo M. Half-century research developments in maritime accidents: Future directions / M. Luo, S. Shin // Accident Analysis \& Prevention. - 2019. - Vol. 123. - P. 448-460. DOI: 10.1016/j.aap.2016.04.010

4. Research of Relationship between the Social Expectations and Professional Training of Lyceum Students studying in the Field of Shipbuilding / [I. S. Popovych, O. Ye. Blynova, M. I. Aleksieieva et al.] // Revista Espacios. - 2019. - Vol. 40, Issue 33. - P. 21-34.

5. Popovych I. Psychology of Social Expectations of Personality: Methodology, Theory and Practice [Electronic resource] / I. Popovych // Revista ESPACIOS. - 2019. - Vol. 40(33). P. $21 . \quad$ Access mode: https://www.revistaespacios.com/a19v40n33/19403321.html

6. Identification of "Human error" negative manifestation in maritime transport / [P. S. Nosov, A. P. Ben, V. N. Mateichuk, M. S. Safonov] // Radio Electronics, Computer Science, Control. - 2018. Vol. 4 (47). - P. 204-213. DOI: 10.15588/1607-3274-2018-4-20

7. Approaches going to determination periods of the human factor of navigators during supernumerary situations / [P. Nosov, A. Ben, A. Safonova, I. Palamarchuk] // Radio Electronics, Computer Science, Control. - 2019. - Vol. 2(49). - P. 140-150. DOI: $10.15588 / 1607-3274-2019-2-15$

8. Zinchenko S. M. Automatic collision avoidance with many targets, including maneuvering ones / [S. M. Zinchenko, P. S. Nosov, V. M. Mateichuk et all] // Radio Electronics, Computer Science, Control. - 2019. - Vol. 4. - P. 211 - 222. DOI: $10.15588 / 1607-3274-2019-4-20$
9. Zinchenko S. Automatic collision avoidance with many targets, including maneuvering ones / [S. Zinchenko, P. Nosov, V. Mateichuk et all] // The International scientific and practical conference dedicated to the memory of professor Fomin Y. Y. and Semenov V. S. (FS-2019), Odessa - Istanbul - Odessa, 2428 April, 2019, proceedings. - ONMU, 2019. - P. 343-349.

10. A Scheme on Indoor Tracking of Ship Dynamic Positioning Based on Distributed Multi-Sensor Data Fusion / [J. Xiong, L. Shu, Q. Wang et all] // IEEE Access. - 2016. - Vol. 5. P. 379 - 392. DOI: 10.1109/ACCESS.2016.2607232

11. Fossen T. I. Kalman filtering for positioning and heading control of ships and offshore rigs / T. I. Fossen, T. Perez // IEEE Control Systems Magazine. - 2009. - Vol. 29. - Issue 6. P. 32-46. DOI: 10.1109/MCS.2009.934408

12. Nielsen U. D. A novel approach for navigational guidance of ships using onboard monitoring systems / U. D. Nielsen, J. Jensen // Ocean Engineering. - 2011. - Vol. 38, Issues 2-3. P. 444-455. DOI: 10.1016/j.oceaneng.2010.11.024

13. Peng $X$. Ship motion prediction of combination forecasting model based on adaptive variable weight / X. Peng, B. Zhang, L. Rong // 34th Chinese Control Conference (CCC), 28-30 July, 2015: proceedings. - Hangozhou, China (Lecture Notes in IEEE Xplore. - 2015). DOI: 10.1109/ChiCC.2015.7260259

14. Luo W. Blind Prediction of Ship Maneuvering by Using Support Vector Machines / W. Luo, Z. Zou // 29th International Conference on Ocean, Offshore and Arctic Engineering (ASME 2010), 6-11 June, 2010: proceeding. - Shanghai, Chaina (Lecture Notes in American Society of Mechanical Engineers. 2010. - P. 437-443). DOI: 10.1115/OMAE2010-20723

15. Wu X. Maneuverability prediction for a ship with full-revolving twin propellers / X. Wu, X. Gao // Chinese Journal of Ship Research. - 2017. - Vol. 12, Issue 1, DOI: 10.3969/j.issn.16733185.2017.01.005

16. Chen Y. M. Neural networks-based scheme for system failure detection and diagnosis / Y. M. Chen, M. L. Lee // Mathematics and Computers in Simulation. - 2002. - Vol. 58, Issue 2. P. 101-109. DOI: 10.1016/S0378-4754(01)00330-5 